\title{
DE CURAS, FRAILES Y MONJAS: DISCIPLINA Y REGULACIÓN DEL COMPORTAMIENTO DEL CLERO EN EL OBISPADO DE CALAHORRA, $1500-1700^{*}$
}

\author{
POR \\ ELENA CATALÁN MARTÍNEZ \\ Universidad del País Vasco/Euskal Herriko Unibertsitatea
}

RESUMEN: Este trabajo analiza el cambio en las pautas de comportamiento del clero en el proceso de transformación de la iglesia medieval en una iglesia moderna. El concilio de Trento intentó construir una nueva identidad para los sacerdotes, organizada, pulcra y eficiente al servicio de la fe que la alejara de los intereses y actitudes privados, propios de una iglesia feudal. Era necesario separar con claridad los espacios profanos y sagrados hasta lograr que las relaciones entre ambos universos estuviesen dominadas por la verticalidad. La iglesia post-tridentina apostó por un modelo de santidad basado en el acatamiento de la norma. Los conventos se convirtieron en auténticas fábricas de santos que publicitaron a través de sus crónicas, reforzando la formación de un espíritu identificativo, en el que la iglesia marcaba los códigos de reconocimiento y su exaltación pública.

PALABRAS CLAVE: Concilio de Trento, crónicas, comportamiento clero, clero patrimonial, patronato.

\section{OF PRIESTS, FRIARS AND NUNS: DISCIPLINE AND REGULATION OF BEHAVIOR THE CLERGY OF THE DIOCESE OF CALAHORRA, $1500-1700$}

\begin{abstract}
This paper analyzes the changing patterns of behavior of the clergy and the homogenization of models of holiness, in the process of transformation of the medieval church in a modern church. The Council of Trent tried to build a new identity for the priests, organized, neat and efficient at the service of the faith that would keep it away from private interests and attitudes, typical of a feudal church. It was necessary to clearly separate the profane and sacred spaces to ensure that the interactions between the two universes were dominated by the verticality. The post-Tridentine church opted for a model of holiness based on the compliance with the standard. The convents became real saints factories advertised through their stories, reinforcing the formation of a spirit identification, in which the church guided the recognition codes and its public excitement.

KEYWORDS: Council of Trent, behavioural clergy, clergy patrimonial, patronage, chronic foundational.
\end{abstract}


Recibido/Received

Aceptado/Accepted
26-05-2012

28-02-2013

\section{INTRODUCCIÓN}

La identificación de la monarquía hispana como paradigma de cristiandad fue fundamental en el proceso de construcción de su propia identidad frente al resto de los estados europeos. ${ }^{1}$ La misión evangélica, militante y civilizadora en América, la defensa de la fe católica y los intereses nacionales frente a otras confesiones, formaron parte de la concepción política-religiosa llevada a cabo durante la Reconquista y consolidada en el absolutismo confesional instaurado por Felipe II. La formación de un estado moderno, centralizado y sacralizado exigía la profesionalización del sacerdocio y la homologación de sus miembros. ${ }^{2}$

A partir de la segunda mitad del siglo XV, se inició en la Península un amplio movimiento de regeneración de la Iglesia en el que el valor de la historia y el control de la memoria resultaron fundamentales. La aparición de las herejías protestantes obligó a la iglesia romana a elaborar una estrategia global que legitimara parcelas de poder, justificara los escenarios de confrontación ideológica con la iglesia reformada, y permitiera el rearme ideológico y moral de la sociedad. El concilio de Trento trató de dar respuesta a las nuevas exigencias, a través de una estricta jerarquización de sus estructuras para asegurar la sumisión de laicos y eclesiásticos al dogma de la Iglesia. Confesionalización y disciplinamiento fueron dos de los referentes sobre los que se desarrolló la contrarreforma y la clave interpretativa de una parte importante de la historiografía. ${ }^{3}$

*Trabajo realizado en el marco de los proyectos de investigación HAR2011-28732-C03-02, del Ministerio de Economía y Competitividad. Secretaria de Estado de Investigación, Desarrollo e Innovación, y 11863/PHCS/09 de la Fundación Séneca. Agencia de Ciencia y Tecnología de la Región de Murcia. Así mismo, la autora pertenece al grupo de Investigación IT807-13 del Sistema Universitario Vasco financiado por el Departamento de Educación, Universidades e Investigación del Gobierno Vasco.

${ }^{1}$ Navarro, A.M. 2010. "Los santos y el imaginario urbano en los discursos historiográficos: Andalucía siglos XIII-XVII". Hispania Sacra 126: 458.

${ }^{2}$ Sangalli, M. 2007. "La formación del clero católico en la Edad Moderna. De Roma, a Italia, a Europa". Manuscrits 25: 103-106.

${ }_{3}$ La bibliografía en torno a las categorías mencionadas -disciplinamiento y confesionalización- es bastante amplia. Limitaré las referencias a sólo algunos trabajos que han desarrollado el estado de la cuestión y que contienen un repertorio bibliográfico bien nutrido. Palomo, F. 1997. "Disciplina christiana. Apuntes historiográficos en torno a la disciplina y el disciplinamiento social como categorías de la historia religiosa de la Alta Edad Moderna". Cuadernos de Historia Moderna 18: 119-136. Del mismo autor, en 2005, "Hispania Catholica. Balance y perspectivas para el estudio de la historia religiosa de España y Portugal en la época confesional", en E. Serrano, A.L. Cortés Peña y J.L Betrán (Coords.), Discurso religioso y Contrarreforma: 221272. Zaragoza: Institución Fernando el Católico. También, Ruiz-Rodríguez, J.I y Sosa Mayor, I. 2007. "El concepto de la "confesionalización" en el marco de la historiografía germana". Studia Historica. Historia Moderna, 29: 279-305. También cabe mencionar el monográfico que publicó en 2007 la revista Manuscrits. Revista d'història moderna 25, bajo el título "Confesionalizació i disciplinament social a l'Europa católica (segles XVI-XVIII)". 
Las disposiciones tridentinas, sobre el ejercicio del poder, se prestaron a múltiples interpretaciones, por lo que su aplicación constituyó la definición de la propia reforma. ${ }^{4}$ En España, Felipe II se erigió líder del cambio, eliminando cualquier interferencia del papado en la disciplina de sus reinos: el derecho de presentación de los candidatos a las sedes episcopales vacantes le permitió controlar la jerarquía del clero hispano y, a través de ella, dirigió la reforma favoreciendo el fortalecimiento de la identidad nacional y el disciplinamiento social. ${ }^{5}$ La cura de almas y la labor pastoral se convirtieron en los principales instrumentos rectores de la acción de la Iglesia, encaminados a la interiorización de las nuevas normas y modelos de conducta. ${ }^{6}$ Se dio carta de naturaleza sacramental a los principales actos de la vida del individuo —nacimiento, matrimonio y muerte - y se eliminó cualquier posibilidad de indiferencia o neutralidad; se trataba de vivir en el dilema del bien contra el mal, la gloria eterna frente al temor de la condena a una muerte eterna. ${ }^{7}$ No obstante, se permitió el arrepentimiento y la expiación de los pecados a través de la oración, las misas o las limosnas ${ }^{8}$, y se otorgó poder de intercesión e invocación a los santos para alcanzar el perdón de los pecados. ${ }^{9} \mathrm{La}$ iglesia post-tridentina apostó por un modelo de santidad basado en el acatamiento de la norma que superase la virtud heroica y el empeño religioso de emular al primitivo pueblo cristiano. ${ }^{10}$

La unificación de la liturgia, el fomento de la vocación mariana o los procesos de santificación constituyeron un claro vehículo para la formación de un espíritu identificativo, en el que la iglesia marcaba unos códigos de reconocimiento y su exaltación pública. Las vidas de santos, los martirologios, pasionarios o sermones cumplieron una labor pedagógica ejemplar, ya que potenciaron determinadas actitudes y comportamientos entre los fieles. La Iglesia premiaba la excelencia con un extenso calendario de celebraciones y veneración de las imágenes, que prestigiaban los lugares de culto, sacralizando la identidad pública de villas y ciudades.

${ }^{4}$ Fernández Terricabras, I. 2000. Felipe II y el clero secular. La aplicación del concilio de Trento:364. Madrid: Sociedad Estatal para la conmemoración de los centenarios de Felipe II y Carlos V.

5 Ibídem: 380

6 Ibídem: 374-375

7 Soto Rábanos, J.M. 2006. "Visión y tratamiento del pecado en los manuales de confesión de la Baja Edad Media Hispana". Hispania Sacra 118:418

8 "... que hay Purgatorio; y que las almas detenidas en él reciben alivio con los sufragios de los fieles, y en especial con el aceptable sacrificio de la misa; manda el santo Concilio a los Obispos que cuiden con suma diligencia que... se enseñe y predique en todas partes, y se crea y conserve por los fieles cristianos" Sacrosanto, Ecuménico y General Concilio de Trento. 1563. Sesión XXV. Decreto sobre el Purgatorio. Biblioteca Electrónica Cristiana (B.E.C.) (en adelante C.T.)

9 "...sobre la intercesión e invocación de los santos, honor de las reliquias, y uso legítimo de las imágenes [...] que es bueno y útil invocarlos humildemente, y recurrir a sus oraciones, intercesión, y auxilio para alcanzar de Dios los beneficios por Jesucristo su hijo, nuestro señor, que es sólo nuestro redentor y salvador", ídem.

${ }^{10}$ Caffiero, M. 1994. "Tra modelli di disciplinamento e autonomia soggettiva", en Barone, G; Caffiero, M y Scorza, F (ed.) Modelli di santità e modelli di comportamento: 265-266 Torino: Rosenberg\&Sellier. 
La promoción de la contrarreforma produjo una auténtica eclosión milagrera que respondía al gusto de la sociedad barroca por lo truculento, lo fantástico e imaginario. Los libros sobre las vidas y milagros de los santos, se convirtieron en las piezas más codiciadas de cualquier biblioteca, mientras que la iglesia española iniciaba una frenética actividad diplomática para lograr beatificaciones 0 canonizaciones de sus hijos predilectos. Cada orden religiosa tenía su propia "receta" para situar al mayor número posible de sus miembros en los altares, difundiéndolo a través de las crónicas de cada congregación. Con ello, pretendían consolidar su influencia en la sociedad, atraer a un buen número de aspirantes, incrementar la cuantía de las limosnas o conseguir el patrocinio de la nobleza, que era lo que permitía mantener la infraestructura desde un punto de vista económico.

A lo largo de estas páginas, se pretende analizar el proceso de transformación de la iglesia medieval, fuertemente imbuida de un espíritu guerrero y nobiliario, en una iglesia moderna, al servicio de la monarquía. Las pautas de comportamiento establecidas, tanto para el clero secular como para el regular, fueron producto de una estrategia encaminada a consolidar el poder social de la Iglesia y a regular las relaciones sociales y personales de la feligresía. Los párrocos, al frente de una tupida y extensa red de parroquias, fueron los encargados de difundir la ortodoxia tridentina. Investidos de poder absolutorio, se situaron en un plano superior desde el que podían ejercer un gran poder fiscalizador de actitudes y comportamientos. Conscientes del valor didáctico del ejemplo, los curas debían evitar cualquier actitud pública que pudiera contradecir el mensaje que se pretendía difundir. ${ }^{11}$ Así, se exaltaba y santificaba a aquellos sacerdotes que, aún viviendo en estrecho contacto con las tentaciones del mundo, eran capaces de erigirse en modelo de piedad, honradez y rectitud. La jerarquía, consciente de que la vida en el siglo dificultaba enormemente el seguimiento de este modelo, buscó en la vida conventual el contrapunto edificante que permitiera alcanzar la perfección, a mayor gloria de Dios. La reforma descalza de los conventuales proporcionó un extenso elenco de vidas ejemplares que satisficieron las necesidades de una sociedad ávida de sucesos extraordinarios y cubrieron la demanda creciente de santos a los que dirigir plegarias, súplicas y limosnas.

El estudio tiene dos partes bien diferenciadas. La primera se centra en el proceso de disciplinamiento del clero secular, en un área geográfica que comprende las actuales comunidades de La Rioja, País Vasco y Navarra, con una fuerte presencia de iglesias de patronato laical y de beneficios patrimoniales. ${ }^{12}$ Para ello, he utilizado fundamentalmente los informes que los obispos enviaban a Roma, las disposiciones sinodales y las visitas pastorales ya que ofrecen un corpus teórico con evidente función reguladora pero que, a la vez, evidencian una

11 "No hay cosa que vaya disponiendo con más constancia los fieles a la piedad y culto divino, que la vida y ejemplo de los que se han dedicado a los sagrados ministerios; pues considerándoles los demás como situados en lugar superior a todas las cosas de este siglo, ponen los ojos en ellos como en un espejo, de donde toman ejemplos que imitar" C.T. Sesión XXII. Decreto sobre la reforma, canon I.

${ }^{12}$ Sobre esta cuestión se ha publicado recientemente Irigoyen, A. y Crespo, F.J. 2013. "Sínodos pretridentinos de Calahorra y Pamplona: La Iglesia y la regulación de la sociedad campesina" en $\mathrm{M}^{a} \mathrm{~J}$. Pérez y A. Martín (eds.); F. Fernández Izquierdo (col.) Campo y campesinos en la España Moderna. Culturas políticas en el mundo hispano: 1327-1336. León: Fundación Española de Historia Moderna. 
preocupación por las autoridades por corregir conductas de los clérigos que no se ajustaban a derecho. ${ }^{13}$ A pesar de las evidentes limitaciones de este tipo de fuentes, ofrecen una excelente imagen en negativo del modelo de comportamiento que se esperaba tanto de la clerecía como de sus feligreses. El concilio de Trento dedica una gran cantidad de cánones a regular la actividad pastoral de los clérigos y de la influencia que deben ejercer sobre a sociedad a la que sirven, siendo el corpus teórico en el que sustenta la figura del párroco ideal. La segunda parte, está dedicada a los modelos de comportamiento que el clero regular establece para sus miembros. Cada orden muestra una "hoja de ruta" a través de la cual alcanzar el grado máximo de perfección en la búsqueda de la santidad. Las crónicas de cada orden, a pesar de ser un género panegírico y apologético, se insertan en el universo cultural y religioso barroco que contribuyeron a conformar. ${ }^{14}$ Por ello constituyen un elemento extraordinariamente útil para explorar el universo mental colectivo de monjas, frailes, la percepción de sí mismos y la percepción del mundo. ${ }^{15}$ Para este trabajo se han analizado las crónicas de franciscanos, carmelitas y trinitarios con implantación en la región ${ }^{16}$

\section{VIVIR EN EL SIGLO. EL DIFÍCIL CAMINO DE LA VIRTUD}

La transformación del clero medieval, cuyas relaciones con la feligresía estaban regidas por la horizontalidad, en un clero integrado en una estructura jerárquica y moralmente diferenciado de los laicos fue lenta y tortuosa.

En la sociedad medieval, el verdadero valor religioso y la vida ascética lo representaban los monasterios. La función del clero secular consistía, básicamente, en la administración de los sacramentos y en la trasmisión oral de la verdad revelada; no se exigía una formación cualificada ya que bastaba con unas nociones básicas de lectura, escritura, canto eclesiástico e historia sagrada. ${ }^{17}$ En los reinos cristianos peninsulares, al igual que en el Imperio Carolingio, predominaban las iglesias propiedad de la nobleza que no reconocían la autoridad del obispo y que

${ }^{13}$ Se han analizado las visitas ad limina del obispado de Calahorra y la Calzada entre 1616 y 1795 (ASV (Archivo Secreto del Vaticano). Relationes 167 A-167B]; las constituciones sinodales de los obispos Bernal de Luco de 1553, Pedro Manso de 1601, González del Castillo de 1621 y Pedro Lepe de 1698; así como mandatos episcopales recogidos en documentación parroquial.

${ }^{14}$ Atienza, A; Catalán, E; Muñoz, F. 2011. Conventos de la Rioja. Su historia en las crónicas religiosas de época barroca: 36. Logroño: Instituto de estudios Riojanos. Sobre el conjunto de la producción historiográfica y panegirista de la época pueden verse las distintas contribuciones recogidas en Atienza, A. (ed). 2012. Iglesia Memorable. Crónicas, historias, escritos... a mayor gloria. Siglos XVI-XVIII. Madrid: Sílex.

${ }^{15}$ Egido, T. 1994. "Mentalidades colectivas del clero regular del Antiguo Régimen", en E. Martínez Ruiz y V. Suárez Grimón (eds): Iglesia y Sociedad en el Antiguo Régimen: 555-572. Las Palmas de Gran Canaria: Universidad de las Palmas de Gran Canaria.

${ }^{16}$ Las crónicas franciscanas consultadas son: Garay, Fr. M. 1742. Compendio chronológico con nuevas adiciones a la Primera parte de la Crónica de la Santa Provincia de Burgos, Pamplona; Hernáez de la Torre, Fr. D., y Saénz de Arquiñigo, Fr. J. 1722. Primera Parte de la Chronica de la Provincia de Burgos de la Regular Observancia de Nuestro Padre San Francisco, Madrid. Las del Carmelo descalzo: Santa María, Fr. F. 1655. Reforma de los Descalzos de Nuestra Señora del Carmen de la primitiva observancia hecha por Santa Teresa de Jesús en la antiquíssima Religión fundada por el gran profeta Elías. Tomo Segundo: 504-515. Madrid. y de los mercedarios: Vega y Toraya, Fr. F. de la. 1723. Chronica de la Provincia de Castilla y León, y Navarra del orden de la Santíssima Trinidad, Redempción de Cautivos. Segunda parte: 675-681. Madrid.

17 Sala Balust, L. y Martín Hernández, F. 1966. La formación sacerdotal en la Iglesia: 19-25. Barcelona: Juan Flors editor. 
tenían control absoluto sobre sus clérigos. La reforma gregoriana se centró en reforzar la autoridad episcopal sobre los sacerdotes, por encima de los monasterios o de los señores laicos, prestando especial atención a la formación permanente y al abuso en la acumulación de prebendas. ${ }^{18}$ Sin embargo, la dotación económica al ejercicio del ministerio sagrado - beneficio- ejerció un potente atractivo sobre aspirantes de dudosa vocación, haciendo infructuosos los esfuerzos por elevar la condición moral e intelectual de los clérigos. ${ }^{19}$ El ejercicio del sacerdocio, entendido como un bien patrimonial, la escasa cohesión del poder episcopal y el perfil caballeresco de las dignidades eclesiásticas, ${ }^{20}$ no ayudaron a corregir determinados comportamientos considerados poco adecuados en un clérigo: implicación en actos violentos, participación activa en fiestas, bailes y juegos, incontinencia sexual... Según Muro Abad, la sociedad medieval toleraba estos excesos ya que veía en los pecados del clero una cierta garantía de benevolencia para los suyos. ${ }^{21}$

A partir del siglo $\mathrm{XV}$, los cánones y el capitulado conciliar reiteran las disposiciones para conseguir de la clerecía conductas de decoro, gravedad, honradez, decencia, seriedad, mesura, majestad, respeto y solemnidad. ${ }^{22}$ En primer lugar era necesario reforzar la estructura jerárquica de la Iglesia para que el clero, controlado y sometido al poder episcopal, pudiera observar unas estrictas pautas de comportamiento; en segundo lugar, la jerarquía debía procurar una correcta "formación profesional" de sus bases que acentuara el carácter estamental y el papel director de la Iglesia en la sociedad; y por último, se debía romper con la horizontalidad que presidía las relaciones con la feligresía, separando con claridad los espacios profanos y sagrados hasta lograr que las relaciones entre ambos universos estuviesen dominadas por la verticalidad. El concilio de Trento intentó construir una nueva identidad para los sacerdotes, organizada, pulcra y eficiente al servicio de la fe que la alejara de los intereses y actitudes privados, propios de una iglesia feudal. Esta nueva identidad habría de tener tres vertientes complementarias: el sometimiento del clero a la autoridad episcopal, la clara

${ }^{18}$ A partir del III concilio de Letrán (1179) comenzaron a especificarse los conocimientos teóricos y cualidades morales que debía poseer un clérigo, y a establecer quienes estaban cualificados para impartir enseñanzas eclesiásticas. Hernández, J.L. y Sánchez, L. 2010. "Hacia la racionalización de la formación sacerdotal: orígenes, tentativas y el Concilio de Trento (1545-1563)". Educa B. Revista de la escuela de educación, 2: 80

${ }^{19} \mathrm{El}$ resultado fue un clero mediocre e ignorante hasta el punto que el Sínodo de Rávena (1311) se conformó con exigir tan sólo leer y cantar el oficio a los párrocos; leer, escribir y cantar a los canónigos de las catedrales y nada más que leer para ser prebendado de una colegiata (Jedin, U. 1963. "L'importanza del decreto Tridentino sui seminarinella vita della Chiesa". Seminarium 2: 396-399)

20 Martín García, obispo de Calahorra (1283-1286) llegó a obispo tras tener cuatro hijos y haber sido ordenado sacerdote los últimos cuatro años de su vida (cit, Sáenz Ripa, E. 1990. Los obispos de Calahorra en la Edad Media (siglos VIII-XV):49-50. Logroño: Instituto de Estudios Riojanos)

${ }^{21}$ Muro Abad, J.R. 1994. "El clero diocesano vasco en los siglos XV y XVII: una imagen" en E. García Fernández (dir.), Religiosidad y sociedad en el País Vasco (s. XIV-XVI): 56. Bilbao: Servicio editorial de la UPV/EHU. La reprobación moral que aún hoy hacemos de determinadas conductas, y la calificación de fracaso en la generalización de determinados códigos morales, vino impuesta precisamente por la moral ortodoxa que se diseñó en Trento y que se prolongó más allá de las revoluciones burguesas.

22 Irigoyen, A. 2008. "Los tratados de perfección sacerdotal y la construcción de la identidad social del clero en la España del siglo XVII” Hispania, 230: 724-726 
diferenciación entre regulares y el seculares y un comportamiento público sustancialmente diferente del de los laicos que les elevara en dignidad y promoviera a los fieles a la piedad. En definitiva se trataba de primar el oficio frente al beneficio.

\section{El sometimiento del clero a la autoridad episcopal.}

La aplicación de los decretos tridentinos no fue uniforme ni tuvo la misma intensidad en todas las diócesis. En el norte peninsular, los obispos no lograron reforzar las estructuras parroquiales ni erradicar las formas arcaicas de organización, por lo que el clero sólo modificó parcialmente su conducta. ${ }^{23}$

Las autoridades eclesiásticas encontraron muchísimas dificultades para ejercer su labor reformadora: el poblamiento disperso multiplicaba el número de parroquias y de clérigos, favoreciendo que la visita pastoral se dilatara en el tiempo o se delegara a terceros con la consiguiente pérdida de efectividad; la configuración geográfica de diócesis como Burgos, Calahorra o Pamplona alejaban a los arciprestazgos costeros y montañosos del centro episcopal; la abundancia de clero patrimonial restringía las posibilidades de elección del candidato idóneo para la acción pastoral; la persistencia del régimen de patronato laical convertía a los templos, y sus servidores, en propiedad del usufructuario, siendo utilizados como moneda de cambio de favores y mercedes. En Vizcaya y Guipúzcoa, a todos estos problemas, hubo que añadir el no reconocimiento de la autoridad del obispo por ser considerado como un poder ajeno al sistema foral.

La mayoría de las iglesias vizcaínas y guipuzcoanas pertenecían, por derecho de fundación o donación real, a patronos legos. Éstos se opusieron con vehemencia a que sus clérigos quedaran bajo jurisdicción episcopal y, por lo tanto, a pagar los tributos que le debían en reconocimiento de su potestad. ${ }^{24}$ El fuero viejo sancionó la costumbre de impedir la entrada del obispo a territorio vizcaíno, convirtiéndola en ley. ${ }^{25}$ Finalmente en 1543, y tras siglos de lucha, don Juan Bernal Díaz de Luco, obispo de Calahorra, consiguió que se le permitiera la entrada al Señorío. El permiso se circunscribía a asuntos de materia canónica, ya que seguía teniendo prohibido el ejercicio del poder jurisdiccional sobre laicos que hubiesen cometido cualquier delito eclesiástico, y cualquier injerencia, o averiguación, en asuntos de patronato. ${ }^{26}$ Acogiéndose al principio de exención fiscal, que regía en el Señorío, todas las iglesias quedaron exentas del pago de la tercia episcopal que le

${ }^{23}$ Este éxito incompleto de la Contrarreforma en la periferia peninsular ha sido puesto de manifiesto en Wright, A.D. 1991. Catholicism and Spanish Society under the reign of Philip II and Philip III, Lewiston-Queenston-Lampeter: The Edwin Mellen Press.

${ }^{24}$ Sobre este conflicto véase Catalán, E. 2012b. "La parroquia, ese oscuro objeto de deseo: patronato, poder y conflicto en el País Vasco (s. XIII-XVII)" en Ma J. Pérez y A. Martín (eds.); F. Fernández Izquierdo (col.) Campo y campesinos en la España Moderna. Culturas políticas en el mundo hispano: 643-652. León: Fundación Española de Historia Moderna.

${ }^{25}$ Otro sí dijeron que por cuanto antiguamente habian de fuero e uso e costumbre, que en el dicho condado, non entrare Obispo, nin sus vicarios nin otro..." Fuero Viejo de 1492, en De Cisneros,C.; Larhacha, E; Lorente, A.; Martínez, A. (compiladores) 1986. Fuentes jurídicas medievales del Señorío de Vizcaya: capítulo 227: 165. San Sebastián: Eusko-lkaskuntza.

${ }^{26}$ Mañaricúa, A. 1975. "Problemas religiosos en la Vizcaya de los siglos XIV y XV; régimen monasterial, jurisdicción episcopal y decadencia religiosa", en La sociedad vasca rural y urbana en el marco de la crisis de los siglos XIV y XV: 256. Bilbao: Diputación Foral de Vizcaya. 
hubiese correspondido en reconocimiento de su jurisdicción. ${ }^{27} \mathrm{El}$ interés de los patrones era doble: político, ya que evitaron la intromisión episcopal en las luchas banderizas, y económico, puesto que percibían, en muchos casos íntegramente, la masa decimal y otras rentas a cambio de la obligación de mantener el culto. ${ }^{28} \mathrm{El}$ reiterado incumplimiento, por parte de los patrones, de sus obligaciones económicas motivó la queja constante de los obispos al rey que, como señor de Vizcaya y dueño de la mayoría de las iglesias, era el único que podía imponer sanciones vinculantes. Las tensiones entre el obispado y los propietarios de las iglesias no cesaron de sucederse, llegándose incluso a solicitar la intervención del corregidor para garantizar la seguridad de los delegados episcopales en el ejercicio de sus funciones. La iglesia continuó reclamando sus derechos, hasta bien entrado el siglo XVIII, consiguiendo únicamente éxitos parciales. ${ }^{29}$

La persistencia de iglesias de patronato laical y la debilidad del poder episcopal en las vicarías costeras, favoreció la presencia de un clero patrimonial con fuertes vínculos familiares y clientelares, escasamente formado en materia canónica y doctrinal e insuficientemente dotado desde un punto de vista económico.

\section{La consideración del sacerdocio como un bien familia}

Uno de los principales problemas que tuvieron que atajar los obispos de las diócesis norteñas fue la consideración del sacerdocio como un bien familiar, susceptible de ser transmitido por herencia sin tener en cuenta ni la vocación ni la formación de los beneficiarios. ${ }^{30}$ El mayor escollo no se encontraba en los clérigos que servían en iglesias de patronato laical, y que eran designados por el patrón entre sus parientes más o menos cercanos, sino en la transmisión del beneficio a la descendencia espuria, ${ }^{31}$ producto del concubinato eclesiástico.

La reforma gregoriana había establecido de manera definitiva una rígida moral sexual, que afectaba tanto a laicos como a eclesiásticos, en la que cualquier relación no reglada se consideraba una transgresión de la norma y por lo tanto punible. $^{32}$ La cuestión del celibato eclesiástico estuvo presente desde el siglo XIII en la mayoría de los concilios hispanos, ${ }^{33}$ pero no se impuso como norma de

${ }^{27}$ Solo en Álava, se estableció un canon fijo -las tasaciones de Álava- como símbolo de antiguos derechos jurisdiccionales de la diócesis de Armentia (incorporada a Calahorra en el siglo XII).

${ }^{28}$ Catalán, E. 2000: 41-45

29 “...Y para sostener los autos de visita ha seguido muchísimos pleitos mui costosos... y actualmente los estoy siguiendo con otros muchos [lugares] del Señorío de Vizcaya donde resisten la visita de sus Yglesias y libros de baptismos y demás fundaciones pías, por decir que son de Real Patronato, a cuyos tribunales abocan las causas, haciéndolas interminables y ocasionando dispendios insoportables" A.S.V. Relationes, 167-A. Visita de Don José Espejo y Cisneros. 1725

${ }^{30}$ En todos los obispados se dictan disposiciones que intentan erradicar esta situación hasta bien entrado el siglo XVIII, por lo que estamos ante un problema recurrente y de difícil solución.

${ }^{31}$ Hijos ilegítimos por impedimento matrimonial de los padres como por ejemplo, orden sacra, voto de castidad o parentesco dirimente.

${ }^{32}$ Para los laicos se definieron las líneas esenciales del sacramento del matrimonio especialmente la indisolubilidad y las normas sobre la consanguinidad, mientras que para los eclesiásticos se decretaba la castidad como símbolo de perfección.(Arranz Guzmán, A. 2008. "Celibato eclesiástico, barraganas y contestación social en la Castilla bajomedieval". Espacio, Tiempo y Forma, Serie III, Historia Medieval, 21: 20-21)

${ }_{33}$ Concilios de Lérida (1257), Valladolid (1322), Salamanca (1335), Tortosa (1429), Toledo (1473) y Sevilla (1512). (cit. Muro Abad, J.R. 1993. "La castidad del clero bajomedieval en la 
obligado cumplimiento hasta el concilio de Basilea (1431-48) coincidiendo con la institucionalización del mayorazgo entre la nobleza laica. A partir de entonces, los decretos conciliares, las disposiciones sinodales y los informes de las visitas ad limina insistieron reiteradamente en la necesidad de mantener una conducta ejemplar, o al menos discreta, que evitara escándalo público, ya que el valor de la fama tenía un gran capacidad divulgadora. ${ }^{34}$ No obstante, la Iglesia diferenció entre la incontinencia puntual, a la que se califica como pecado de lujuria, y el concubinato público, tipificado como delito.

La convivencia familiar de los clérigos con sus barraganas e hijos fue habitual en el arco cantábrico, donde predominaban los beneficios patrimoniales y las iglesias de patronato. Por todo el norte peninsular se repetían disposiciones similares a ésta, emitida en el obispado de Calahorra: que ningún hijo bastardo de clérigo ayude en público a missa, ni a los oficios divinos a su padre... lo qual se hace muchas vezes según somos informados quando los hijos ilegítimos de los clérigos sirven a sus padres públicamente en el altar. ${ }^{35}$ Este comportamiento, especialmente si era público y notorio, fue reprendido y sancionado severamente por las autoridades eclesiásticas, ya que implicaba una transgresión consciente de la norma y se corría el riesgo de acentuar la patrimonialidad del oficio al ser transmitido a sus vástagos, tras obligada dispensa papal. ${ }^{36}$ El celo reformador de los prelados se tradujo en una amplia legislación sinodal en la que se amonestaba a los clérigos estableciendo un mecanismo punitivo que atacaba al origen del problema: el sistema beneficial. ${ }^{37}$ La prevalencia del beneficio sobre el oficio animó a muchas familias a dotar patrimonialmente a algunos de sus miembros, como una forma de completar y consolidar el patrimonio familiar ante el avance de la vinculación. Segundones, ramas laterales de la familia o personas unidas al fundador por lazos de clientelismo accedieron a las órdenes sagradas sin ninguna vocación sacerdotal ni preparación eclesiástica. Así, en el seno de una misma parroquia, empezaron a convivir beneficios curados, beneficios simples, capellanes y ordenados a menores, lo que complicaba sobremanera la identificación de los diferentes categorías clericales y la homogeneización de sus comportamientos. ${ }^{38}$ Para la feligresía, todos eran clérigos, sin importar si estaban ordenados de mayores, de menores o simplemente gozaban de alguna capellanía laical. ${ }^{39}$ Trento, en su decreto sobre clérigos concubinarios, estableció una clara diferencia entre los beneficiados y aquellos que no tenían beneficios eclesiásticos ni pensiones. La

diócesis de Calahorra”, Historia. Instituciones. Documentos, 20: 264)

${ }^{34}$ En los tratados de perfección sacerdotal de los siglos XVI y XVII se insiste en su papel educador, de espejo en el que se mira la sociedad.(Irigoyen, A. 2008: 718-722)

${ }^{35}$ Constituciones Synodales del Obispado de Calahorra y La Calçada... Don Ion Bernal de Luco, obispo de dicho obispado.... Logroño, 1553

${ }_{36}^{36}$ A.S.V. Relationes 167-A. Visita de Pedro González del Castillo.1624.

37 Catalán Martínez, E. 2004. "El derecho de patronato y el régimen beneficial de la iglesia española en la Edad Moderna”. Hispania Sacra, 113: 135-168.

${ }^{38}$ El III concilio de Letrán (c. 14) dice textualmente: "que todos se esfuercen en vivir según la continencia y la castidad, sobre todo aquellos que están ordenados de órdenes mayores" (cit. Sánchez Herrero, J. 2008. "Amantes, barraganas, compañeras, concubinas clericales". Clío \& Crímen 5: 128).

${ }^{39}$ Por ejemplo, en el obispado de Barcelona, de los 4.502 clérigos que se censaron entre 1548-49 únicamente el 6,56\% tenían un presbiterado mientras que el $20 \%$ convivía con mujeres. ( Cfr. Bada, J. 1970. Situació religiosa de Barcelona en el segle XVI.: 55-60. Barcelona: Balmes [cit. Por Puigvert, J, 2001. Església, territorio i sociabilitat (s. XVII-XIX): 53. Vic: Eumo editorial]). 
responsabilidad del correcto comportamiento de los primeros recaía directamente sobre el obispo, quien debía aplicar a la fábrica, u otra obra pía, la tercera parte de las rentas del infractor; si reincidiese se le privaría de la totalidad del beneficio y, en última instancia, se procedería a la excomunión. Con respecto a los segundos, no podían sancionarlos con penas económicas puesto que sus dotaciones provenían de fundaciones privadas y las condiciones de fundación podían no establecer la obligatoriedad del orden sacerdotal. Por ello, se les castiga con pena de cárcel suspensión del ejercicio de las órdenes, e inhabilitación para obtener beneficios. ${ }^{40}$

La frecuencia de este tipo de conducta lleva a Josué Fonseca a preguntarse si realmente los clérigos tenían sensación de estar contraviniendo una norma tan importante. ${ }^{41}$ En su análisis del clero cántabro aporta un sinfín de testimonios en los que la vida familiar del clérigo era considerada normal y destaca la aparente contradicción de las fuentes eclesiásticas que se ajustan a la normativa condenando este tipo de actitudes y, simultáneamente, reflejan condescendencia para aquellos clérigos que la transgreden. Por ejemplo, los obispos emitían frecuentemente disposiciones favorables sobre un clérigo, a pesar de su deshonestidad, o se otorgaban licencias de sacerdocio a aquellos hijos que deseaban continuar la carrera de su padre. El decreto tridentino sobre el acceso de los hijos de los clérigos a la carrera eclesiástica comenzaba con una auténtica declaración de intenciones: que se destierren muy lejos de los lugares consagrados a Dios, en donde conviene que haya la mayor pureza y santidad, los recuerdos de la incontinencia de los padres. ${ }^{42}$ En realidad, soslayaba el origen del problema tratando de evitar el escándalo producido por la imagen de padre e hijo oficiando juntos la misa. A comienzos del siglo XVII, Pedro González del Castillo, obispo de Calahorra, solicitaba del papa que dejase de emitir dispensas de natalibus a los hijos de los clérigos para ordenarse, ya que estaba demostrado que solían imitar la incontinencia de sus padres. ${ }^{43}$ En Galicia, Arturo Iglesias ha cuantificado el destino profesional de los hijos de los capitulares de la catedral de Santiago, confirmando plenamente la transmisión del oficio. ${ }^{44}$ Esta práctica debió de ser mayor de lo que parece si se consideran las fundaciones de capellanías y beneficios simples usufructuados por sobrinos de clérigos. La argucia era simple, si las licencias de órdenes estaban vedadas para hijos espurios, la relación de consanguineidad se trasladaba hacia la de tío y sobrino, salvando de esta manera el escándalo público. Desde mediados del siglo XVII, las referencias a la transmisión hereditaria del oficio son cada vez menos frecuentes en los informes de los obispos hasta desaparecer, casi por completo, durante el XVIII. No se sabe la cantidad de sobrinos que sucedieron a sus tíos como beneficiados, canónigos u cualquier otro cargo, pero sin duda contribuyeron a limpiar la imagen pública de los cargos eclesiásticos.

${ }^{40}$ C.T. Sesión: Los religiosos y las monjas. Decretos de reforma, canon XIV.

${ }^{41}$ Fonseca, J. 1996. El clero en Cantabria en la edad moderna: un estudio sobre la implantación de la contrarreforma en el norte de España: 175-177. Santander: Servicio de publicaciones de la Universidad de Cantabria.

${ }^{42}$ C.T. Sesión: Los religiosos y las monjas. Decretos de reforma, canon XV.

${ }^{43}$ A.S.V. Relationes, 167-A. (cit por Barrio Gozalo, M. 2010. El clero en la España Moderna: 180. Córdoba: Caja Sur y CSIC).

${ }^{44}$ El 47,06\% de los hijos de capitulares siguieron la carrera eclesiástica. (Iglesias Ortega, A. 2011. "La perpetuación de la sangre: la descendencia ilegítima del alto clero compostelano en el siglo XVI". Manuscrits 29:144). 
Cómo la mujer del César, no sólo debe serlo...sino además, parecerlo.

La Iglesia fue más permisiva con aquellos clérigos que incurrieron en el pecado de lujuria, siempre y cuando no hicieran ostentación pública del mismo. ${ }^{45}$ Se consideraba que el cura, hombre al fin, al estar en contacto directo con la feligresía estaba expuesto a múltiples tentaciones que debía procurar evitar como la excesiva cercanía con el penitente en el confesionario, ciertas preguntas sobre el pecado de la carne que dieran lugar a relatos demasiado explícitos, ${ }^{46}$ o tener un ama de llaves suficientemente joven que diera pie a habladurías. ${ }^{47}$ Pero la carne es débil, y el pecado de lujuria se cebó en todos los órdenes eclesiales.

Si hacemos caso a la reiteración de las sanciones contra este pecado ${ }^{48}$ y la cantidad de espacio que ocupa esta cuestión en los manuales de confesores, podríamos pensar que el problema no se resolvió, máxime si consideramos que los delitos sexuales de los clérigos alcanzaron, entre 1592 y 1622, el 31,7\% de las causas penales de la diócesis de Murcia $^{49}$ y el $19 \%$ de las de Sevilla durante el $X \mathrm{VIII}^{50}$. Ana Arranz llama la atención sobre la gruesa lectura que solemos hacer de ciertas disposiciones episcopales otorgando categoría de norma a comportamientos que pudieron ser puntuales. ${ }^{51}$ Se tiende a obviar que se afea la conducta censurable, pero nada se dice del número de infractores ni del de aquellos que acatan la norma ${ }^{52}$. Además, a medida que los obispos se fueron comprometiendo con el ejercicio de su ministerio en sus diócesis, las medidas correctoras de ciertas conductas se fueron sucediendo con mayor regularidad, lo que puede dar la impresión de un incremento de este tipo de comportamientos. No cabe duda de que la jerarquía eclesiástica se esforzó en separar los espacios religiosos y profanos, incidiendo en la necesidad de que los clérigos llevaran una vida acorde con su hábito, puesto que en una sociedad con un potente imaginario visual, la puesta en escena y la simbología eran imprescindibles para crear una identidad pública que sirviera de ejemplo e invitara a la piedad y el recogimiento. ${ }^{53}$

45 " la infamia de los clerigos, quando se publica, es en opprobio y vilipendio del estado eclesiástico, y pierden el credito y autoridad que deven tener.." Sínodo Asturicense.1553.Synodicon Hispanum, III (cit, Arranz Guzmán, A. 2008: 30).

${ }^{46} E$ acerca de esto (se refiere al pecado de lujuria) ha de ser avisado el confesor que algunas cosas debe dexar de preguntar al penitente, en las quales entiende que no sabe pecar, porque de otra manera sería dar ocasión que allí adelante pecasse en ellas». Ibídem: 22.

47 "que no tengan mancebas, ni mujeres sospechosas en sus casas. Y si alguno tuviere mujer de servicio, que sea sin sospecha y mayor de cuarenta años o parienta suya dentro del tercer grado" Constituciones Sinodales del Obispado de Pamplona, de Bernardo de Rojas y Sandoval, Pamplona, 1591. De cohabitation eclericorum et mulierum (cit. en Muro Abad, J.R. 1994: 58)

${ }^{48}$ Véase Muro Abad, J.R. 1993; Arranz Guzmán, A. 2008; Sánchez Herrero, L. 2008; e Iglesias Ortega, A. 2011.

${ }^{49}$ Irigoyen, A. 2010. "La difícil aplicación de Trento. Las faltas de los capitulares en Murcia (1592-1622). Hispania sacra, 125: 173

${ }^{50}$ Candau Chacón, M ${ }^{\mathrm{a}}$.L, 1993. Los delitos y las penas en el mundo eclesiástico sevillano del XVIII: 89. Sevilla: Diputación provincial.

${ }_{52}$ Arranz Guzmán, A. 2008: 24-25

52 Los estudios realizados en Palencia, Oviedo y Toledo para el siglo XV arrojan un porcentaje de clérigos infractores de entre el 10 y el $20 \%$ del total de los miembros del estamento (Ibídem: 27).

${ }^{53}$ Por ello "deben ordenar su vida y costumbres, que nada presenten en sus vestidos porte, pasos, conversación y todo lo demás, que no manifieste a primera vista gravedad, modestia y religión" Constituciones Synodales de Calahorra y la Calzada,1554, lb III. 
Las constituciones sinodales de los obispados promovieron que los clérigos llevaran una vida de honestidad, decencia y doctrina en la que no tuvieran cabida ni el fasto, ni las convitonas, bailes, dados, juegos y cualesquier otros crímenes. ${ }^{54}$ Leyendo las disposiciones sinodales da la impresión de que importaba más evitar el escándalo, para defender la dignidad del estado clerical, que la erradicación real de estas costumbres. Por ejemplo, Don Juan Bernal de Luco permitió en su obispado de Calahorra que [los clérigos] en lugar secreto dentro de casa, por vía de recreación puedan jugar, en su habito, a la pelota y naipes, colación y en dinero hasta cuatro ducados. ${ }^{55}$ De la misma manera el obispo de Pamplona, Don Bernardo Rojas Sandoval, en un intento por separar lo profano de lo sagrado, amonestó a sus clérigos por celebrar las fiestas y reuniones en las inmediaciones de las iglesias donde se cantaba, bailaba, comía o jugaba ${ }^{56}$ y Trento prevenía contra la costumbre de glorificar a los santos y fiestas de guardar con convitonas $y$ embriagueces como si el lujo y lascivia fuese el culto con que deban celebrar los dias de fiesta en honor de los santos. ${ }^{57}$

La pureza interior de sus costumbres debía manifestarse en la decencia del vestido exterior, ${ }^{58}$ por ello quedó prohibido que un clérigo utilizase ropas seglares, aunque solo estuviera ordenado de menores, portase armas ${ }^{59} 0$ realizase ostentación a través de adornos o telas lujosas. Los tejidos de seda negra con bordones en las sotanas y calzas y jubones de color o blancos, causaban escándalo puesto que atentaban contra la modestia que se exigía al estado sacerdotal, aunque se permitían en el ámbito privado. ${ }^{60} \mathrm{Al}$ parecer, este último aspecto fue más difícil de cumplir para las dignidades capitulares que para el clero parroquial el cual pecaba de desaliño y zafiedad, especialmente en el ámbito rural. 61

\section{La profesionalización del sacerdocio}

Aun siendo fundamental la imagen pública ofrecida por los clérigos, donde verdaderamente se debía manifestar su condición de agentes de una misión superior, era en el ejercicio de la misión pastoral y en la celebración de la misa. Como primer signo de la era tridentina, se procedió a una regulación de la función sacerdotal: se exigió la dedicación exclusiva del oficio, obligando a la residencia de todos los beneficios, desde los prelados hasta el más humilde cura de aldea, y

${ }^{54}$ C.T. Sesión XXII. Decreto sobre la reforma, canon I.

${ }^{55}$ Constituciones Synodales de Calahorra y la Calzada, 1554, Ib III.

${ }^{56}$ Somos informados, que assi en las Iglesias, como en los cimenterios, muchas vezes se atreven a jugar, assi clérigos como legos, y a comer, y beber dentro de las dichas Iglesias...Ordenamos que de aquí adelante ninguna persona ecclesiástica, ni seglar, de qualquier calidad o preeminencia, que sea, pueda velar, ni vele en Iglesia, o hermita de nuestro Obispado, de noche, ni coman, ni dancen en ellas, ni canten cantares deshonestos. (cit. Muro Abad, J.R. 1994:62). imágenes".

${ }^{7}$ C.T. Sesión XXV. "La invocación, veneración y reliquias de los santos, y de las sagradas

${ }^{58}$ C.T. Sesión XIV. Decretos sobre la reforma, canon XV, "Decrétese pena contra los clérigos que ordenados in sacris, o que poseen beneficios, no llevan hábitos correspondientes a su orden".

59 "Que los clérigos de orden sacro no traygan arcabuzes ni escopetas, en los pueblos ni de camino" Constituciones Synodales de Calahorra y la Calzada,1554, Ib III.

${ }^{60}$ Barrio Gozalo, M. 2010: 245-246.

${ }^{61}$ Como el caso de un beneficiado en Cantabria que "...ba sin cuello a la Iglesia, y... limpia las narices con los purificadores". Fonseca, J. 1992: 178. 
arbitrándose un sistema de sustituciones para aquellos casos en los que la ausencia fuera ineludible; ${ }^{62}$ se legisló contra la acumulación de beneficios estableciendo una congrua mínima para la cura de almas, a fin de evitar el pluriempleo sacerdotal, y se unificaron aquellos que resultaban incongruos para ofrecer un servicio eficiente; ${ }^{63}$ se excluyeron del oficio sacerdotal a los que no gozaban de un beneficio o dotación para garantizar la subsistencia; ${ }^{64}$ se exigió la aprobación del ordinario para que los regulares, capellanes o predicadores pudieran ejercer en casas particulares u oratorios privados; ${ }^{65}$ se circunscribió la cura de almas a los seculares ordenados in sacris con licencia del ordinario limitando la acción de los regulares a los beneficios instituidos dentro de sus conventos; ${ }^{66}$ y se limitó el derecho de presentación de los patrones a la mera propuesta del candidato ya que éste debía cumplir los requisitos exigidos y contar con la aprobación del obispo. ${ }^{67}$

La profesionalización del sacerdocio exigía, además de la regulación de la función sacerdotal, una formación especializada y homogénea que permitiera consolidar en todas las parroquias del reino el mismo modelo de beneficiado; y ésta no era fácil de obtener. Trento establecía que en todas las catedrales, metropolitanas, e iglesias mayores que estas tengan obligación de mantener, y educar religiosamente, e instruir en la disciplina eclesiástica, según las facultades y extensión de la diócesis, cierto número de jóvenes de la misma ciudad y diócesis, o a no haberlos en estas, de la misma provincia, en un colegio situado cerca de las mismas iglesias, o en otro lugar oportuno a elección del Obispo. ${ }^{68}$ Para la construcción de estos establecimientos, el pago de los maestros y la alimentación de los aspirantes se proveyeron una dotación de fondos procedente de una parte de los frutos de la mesa episcopal, de las dignidades, oficios y prebendas, de las fábricas de las iglesias y de los diezmos pertenecientes a legos. ${ }^{69}$ La implementación de la red diocesana de formación del clero fue extremadamente lenta: a finales del siglo XVII, sólo 28 de las 55 diócesis españolas poseía un seminario. ${ }^{70}$ Al parecer, la dotación económica prevista por Trento no fue suficiente, o no se consiguió recaudar de manera efectiva, puesto que el principal argumento de los obispos, para justificar la lentitud de la implantación de esta norma, fue la falta de fondos con los que acometer la construcción y mantenimiento de un seminario. Por eso, en la mayor parte del país, el clero continuó formándose

${ }^{62}$ C.T. Sesión VI. Decretos sobre la reforma, cánones I y II.

63 C.T. Sesión VI. Decretos sobre la reforma, cánones IV, V, VI y VII.

${ }^{64}$ C.T. Sesión XXI, canon II.

65 “...que no se permita celebrar Misa a ningún sacerdote vago y desconocido. Tampoco permitan que sirva al altar santo, o asista a los oficios ningún pecador público y notorio: ni toleren que se celebre este santo sacrificio por seculares, o regulares, cualesquiera que sean, en casas de particulares, ni absolutamente fuera de la iglesia y oratorios únicamente dedicados al culto divino." C.T. Sesión XXII, "Sobre lo que se ha de observar y evitar en la celebración de la misa".

${ }^{66}$ C.T. Sesión XIV. Decretos sobre la reforma, cánones X y XI.

${ }^{67}$ C.T. Sesión XIV. Decretos sobre la reforma, cánones XII y XIII.

${ }^{68}$ C.T. Sesión XXIII. Decretos sobre la reforma, canon XIII. En el mismo decreto se explicita los requisitos de los candidatos: ser mayor de 12 años, hijo legítimo, alfabetizado y con buena inclinación moral.

${ }_{70}$ Ídem.

70 Fernández Terricabras, I. 2002. "Universidad y episcopado en el siglo XVI. Las universidades donde estudiaron los obispos de las coronas de Castilla y de Aragón (1556-1598)" Revista de Historia Moderna. Anales de la Universidad de Alicante, 20: 9 
en pequeñas escuelas parroquiales, bajo la supervisión del beneficiado de mayor formación, en las que poder tratar cuestiones morales y doctrinales. ${ }^{71}$

En el caso del obispado de Calahorra y la Calzada, los interminables pleitos que llevaron a cabo los obispos contra los patrones en defensa de su jurisdicción, originaron un constante y excesivo gasto que dejó exhaustas las arcas del obispado impidiendo la erección de un seminario en alguna de las dos iglesias catedrales. ${ }^{72}$ Además el sistema de formación tradicional, que podría haber paliado la ignorancia de los clérigos, era inútil en aquellas zonas en las que la cura de almas se ejercía interinamente por uno de los miembros del cabildo; éstos podían estar ordenados de menores o, simplemente, en posesión de una capellanía laical. El carácter privado de la mayoría de las iglesias y la necesidad de que el cura fuese patrimonial incitaba a numerosos aspirantes a falsificar licencias ${ }^{73}$ o a conseguirlas en obispados menos exigentes ${ }^{74}$. Esta falta de formación se podía suplir con interés y voluntad de servicio a la comunidad, dado que a la mayoría de los curas rurales sólo se les exigía dominar suficientemente las herramientas de su oficio. Según la amplísima tratadística sacerdotal del siglo XVII, lo esencial era que el aspirante al sacerdocio se convenciera, creyera e interiorizara su condición de ser excepcional elegido por Dios para una misión superior. ${ }^{75}$

No obstante, en las diócesis del arco cantábrico, el problema de la escasa calidad intelectual de los clérigos no residía tanto en la falta de formación como en su inserción en un sistema de relaciones clientelares en las que su principal misión consistía en la gestión del capital social y la defensa de los intereses económicos de su patrocinador. El patrón se arrogaba los símbolos de preeminencia social, jurídica y económica, al controlar todos y cada uno de los aspectos de la iglesia, incluidos la cobranza de diezmos y rentas. El clérigo a su servicio se comportaba, vestía y vivía como un miembro más del linaje familiar. El único momento en que se revestía de su condición de hombre sagrado, en el que se distanciaba de la feligresía, era cuando administraba los sacramentos. Por todo ello, era difícil que el clérigo pudiera cumplir con su misión ejemplarizante mostrándose como un hombre austero, humilde y entregado al servicio de la comunidad.

Los manuales de confesores y los tratados de perfección sacerdotal sirvieron de contrapunto para poner ante los ojos de este clero secularizado lo que debiera ser, afeándoles la conducta y procurando que, poco a poco, fueran convirtiéndose se aquello que se esperaba de ellos. Irigoyen, en un magnifico análisis de este

${ }^{71}$ Ibídem: 9-10

72 "que en ninguna de las dos sanctas yglesias avia seminario ecclesiastico...porque mis antecesores consumieron muchos causales en la defensa de su jurisdicción, siguiendo las ynstancias de los tribunales de estos reynos..." A.S.V. Relationes, 167-A. Visita de Don José Espejo y Cisneros. 1725.

${ }^{73}$ En 1700 Don Pedro Lepe suspendía de sus funciones a 17 clérigos, la mayoría poseedores de capellanías por haber presentado licencias falsas de ordenación. Ibídem.

74 “...a los que por ignorantes y falta de título y congrua para ordenarles los prelados de aquí no los ordenan tienen por costumbre de irse al obispado de Astorga y por los medios que pueden adquieren el título de qualquier capellanía y el obispo de allí los admite y con mucha facilidad les da prebendas para todas las órdenes o los ordena y luego se vuelven a residir a este obispado y a sucedido que con una misma capellanía se an ordenado dos en un mismo tiempo y aunque ni mis antecessores ni yo emos querido admitir a los tales ordenados ni darles licencia para celebrar, apelan al metropolitano el qual se la da luego sin que lo podamos remediar... y así está el obispado lleno de clérigos ignorantes y de malas costumbres sin poderlo remediar..." Ibídem. Visita de Gonzalo Chacón Velasco. 1634.

${ }^{75}$ Irigoyen, A. 2008: 729-730. 
género, revela un esfuerzo por consolidar la identidad personal basada en el concepto de dignidad y que , a la vez, sirviera de soporte a la construcción de una identidad social adecuada al estatus clerical (perfección, virtud, santidad y castidad), reconocimiento externo de su superioridad social. ${ }^{76}$ El mensaje fue calando lentamente entre la clerecía y los fieles, de tal manera que, en el siglo XVIII, la conducta de la mayor parte del clero se ajustaba a los cánones tridentinos.

En la diócesis de Calahorra, el poder e influencia de los patrones fue mermando, desde mediados del siglo XVII, lo que facilitó la homologación de sus clérigos. Por una parte, la capacidad económica de los beneficiados que servían en iglesias de patronato, se multiplicó por cinco al permitírseles percibir íntegramente el diezmo de los novales, quedando los derechos de los patrones limitados al dezmatorio original. ${ }^{77}$ Por otra parte, la monarquía había llevado a cabo una política de disgregación del patrimonio eclesiástico de la nobleza al reintegrar a la Corona numerosos patronatos de merced real: unos fueron cedidos directamente a sus cabildos, otros se arrendaron, vendieron o embargaron. ${ }^{78}$ Así, el debilitamiento progresivo de la figura del patrón y la mejora de las condiciones económicas de los curatos, favoreció el éxito de las medidas reformadoras iniciadas bajo el episcopado de Don Pedro de Lepe. ${ }^{79}$ Años más tarde el obispo calagurritano escribe: "Generalmente hablando del clero es de los más hábiles y morigerados, y los Pueblos muy píos, floreciendo en ellos, quanto se puede desear, la religión, la frecuencia de los sacramentos, oración mental y devoción al Santo Rosario, sin que en el día ocurra escándalo, que pida superior remedio". ${ }^{80}$

\section{VIVIR EN EL CLAUSTRO O LA BÚSQUEDA DE LA PERFECCIÓN}

A diferencia del clero secular, la homologación de las pautas de comportamiento de los regulares no presentó ningún problema. La reforma iniciada por el movimiento descalzo se ajustaba perfectamente al modelo de vida conventual impulsado por Trento. Además, la renuncia a la posesión de bienes inmuebles abría la posibilidad de financiarse a través del patrocinio de las élites sociales lo que encajaba muy bien, en el norte de España, con la tradición del patronato y el carácter urbano de las órdenes mendicantes.

Para la Iglesia post-tridentina el único estado de perfección era el que se podía alcanzar viviendo bajo cualquiera de las normativas que regulaban una vida en común y garantizaban la dignidad de aquellos que, renunciando al mundo, se comprometían a llevar una vida ascética, base fundamental de la fama de santidad. Las martiriales quedaron relegadas a un segundo plano, a favor de la vida y milagros de anacoretas, frailes y monjas, y personas que hubieran tenido un

${ }^{76}$ Ibídem. 2008:732-733.

77 Catalán, E. 2010. "La participación del bajo clero en el excedente agrario vasco y riojano (1545-1775)". Investigaciones de Historia económica, 18: 46-47.

78 Catalán, E. 2000. El precio del Purgatorio. Los ingresos del clero vasco en la Edad Moderna: 40-41. Bilbao: Servicio Editorial de la Universidad del País Vasco.

${ }^{79}$ El plan de reforma está contenido en la Carta general que ... Pedro de Lepe, Obispo de Calahorra y la Calzada ... escriue a todo su obispado en razón del silencio, veneración y modestia con que se debe assistir en la iglesias y lugares públicos de oración, y de la enmienda y total extirpación de los muchos abusos que en contrario se experimentan. Logroño 1690.

${ }^{80}$ A.S.V.Relationes 167-B. 1775. Visita de Don Juan Luengo Pinto. 
comportamiento muy parecido al conventual, sobre todo en lo que respecta a la castidad. ${ }^{81}$

La segunda mitad del siglo XVI vivió un auténtico boom de santidad, como respuesta católica a la negación protestante de la capacidad intercesora de la invocación de los santos, el honor de las reliquias y el uso legítimo de las imágenes. ${ }^{82}$ Roma centralizó y monopolizó cualquier iniciativa de culto y veneración como parte de una estrategia de reforzamiento del centro jerárquico de la Iglesia. En consecuencia, las órdenes mendicantes iniciaron una carrera por producir más y mejores candidatos que satisficieran las necesidades de la iglesia reformada y ampliaran su capital de santidad como arma de propaganda frente a las demás congregaciones. ${ }^{83}$

Crónicas fundacionales, anales, memorias, historias de varones ilustres, compendios, historiales, epítomes, apologías o tratados de excelencias dibujan con enorme precisión los rasgos básicos de la santidad. Los cronistas pusieron de relieve las particularidades relacionadas con la defensa del dogma, la promoción de sus santos y de sus historias eclesiásticas, siendo conscientes de formar parte de una entidad política, civil, moral, religiosa y espiritual de características especiales. $^{84}$ El honor de nacimiento, la lealtad a la corona y el patrocinio económico y moral de las clases privilegiadas hacia la empresa emprendida, reflejaban el convencimiento de estar participando en la construcción de la república cristiana ideal.

\section{La vida y milagros según las crónicas: el camino hacia la santidad}

Las crónicas muestran un modo de vida conventual basado en la más estricta observancia de la regla, aun cuando ésta ya se hubiera relajado en el momento de ser escritas. El renunciamiento de uno mismo, la pobreza extrema, el silencio, la clausura, la virginidad, la castidad del cuerpo y del alma, la oración, la devoción y la obediencia perfecta ${ }^{85}$ se muestran como objetivos a alcanzar por aquellos que aspiraban a la perfección. La extensa galería de vidas ejemplares intenta transmitir una eficacia de método y planteamiento frente a otros modos de vida u otras congregaciones.

El ideario descalzo debe mucho al proyecto de Francisco de Asís que preconizaba una vuelta al evangelio, la búsqueda de la paz y el equilibrio interior a través de una vida itinerante y ascética. ${ }^{86}$ En consonancia con este ideal, concibió

\footnotetext{
${ }^{81}$ Egido, T. 2000. "Hagiografía y estereotipos de santidad contrarreformista". Cuadernos de Historia Moderna, 25, monográfico: 68

82 C.T. Sesión XXV. Sobre la invocación, veneración y reliquias de los santos y de las sagradas imágenes.

${ }^{83}$ Sallmann, J.M. 1979. "Il santo e le rappresentazioni della santitá. Problemi di método". Quaderni Storici 41: 584-602 (cit. por Egido, T. 2000: 68 y 70).

${ }^{84}$ Navarro, A. 2010. "Los santos y el imaginario urbano en los discursos historiográficos: Andalucía siglos XIII-XVII”. Hispania Sacra, 126: 458

${ }^{85}$ Estos son los principios que promovían Pedro Villacreces y sus discípulos, grandes transformadores del franciscanismo en el siglo XV. (Rucquoi, A. 1996. "Los franciscanos en el Reino de Castilla", en De la Iglesia, Duarte, García Turza y García de Cortázar (coords.), VI Semana de estudios Medievales. Nájera 31 de julio al 4 de agosto de 1995:78-79. Nájera: Instituto de Estudios Riojanos).

86 " Por aquellos días los frailes llamados menores (...), surgieron inesperadamente y tuvieron una rápida expansión, situándose en las ciudades y villas, viviendo sin propiedades, de sólo el Evangelio, ofreciendo gran ejemplo de humildad en el vestido y en el alimento, caminando descalzos, con túnicas grises remendadas y ceñidas con cordones, encapuchados(...) Comen de lo
} 
la santidad como algo más digno de procurar en uno mismo que de alabar en los demás, despreciando la excesiva e indiscriminada veneración de los santos. ${ }^{87}$ Finalizada la Reconquista, ya no era necesario el martirio para alcanzar la perfección; ésta había dejado de ser una cuestión heroica, de defensa pública de la fe, para alcanzar una dimensión íntima, doméstica, de superación diaria de las dificultades de la vida. La búsqueda de la perfección a través de la ascesis se convirtió en uno de los pilares de la descalcez.

El sufrimiento, íntimamente ligado a la dramatización del sentimiento religioso y al concepto de preparación de la muerte, fue un elemento clave en el tránsito hacia la perfección. Por ello, las crónicas de todas las órdenes reformadas se detienen en la descripción pormenorizada de enfermedades y tormentos que el religioso recibe como émulo de la pasión de Cristo. Abundan las prácticas penitenciales, es decir, castigos auto-infligidos en un sentido disciplinario, para no flaquear en el rigor y limpiar de modo expeditivo las culpas. ${ }^{88}$ En ocasiones, las autoridades eclesiásticas tuvieron que intervenir por los excesos cometidos en ejercicio de tales prácticas, apercibiendo al convento y, en los femeninos, exigiendo la obligatoriedad de la obtención del permiso previo del confesor, que fue el encargado de corregir cualquier exceso. ${ }^{89}$

La exaltación de la perfección individual a través de la mortificación, la humildad y la oración, transcendió de los muros del convento potenciando la utilidad común de la virtud, a través de su manifestación pública. Los conventos masculinos garantizaban una especial asistencia para el consuelo de sus almas, así en el Confessonario, como en el Púlpito y demás ejercicios de virtud; ${ }^{90}$ permitían canalizar los capitales necesarios la redención de cautivos; y mostraban la grandeza del servicio a los demás en un entorno de muerte segura, como una epidemia de peste. ${ }^{91}$ La Iglesia consideraba esta exposición personal a la muerte como un acto de martirio, equiparable al de los primeros cristianos, y afeaba la conducta de aquellos que, siendo religiosos, huían a lugar seguro abandonando a su suerte a sus semejantes. ${ }^{92}$

que les ofrecen (...) Llevan consigo sus libros (...) durante sus viajes” M Parisiensis: Historia Anglorum, MGH, Scritorium XXVIII p, 397. Traducción de J. Garcia Oro, Francisco de Asís en la España medieval, 47: 49-50, cit Fernández Conde, F.J. 2000. La religiosidad medieval en España: Plena Edad Media (ss. XVI-XII). Oviedo: Universidad de Oviedo.

87 Pérez-Embid, J. 2002. Hagiología y sociedad en la España medieval. Castilla y León (siglos XI-XIII): 307. Huelva: Publicaciones de la Universidad de Huelva.

${ }^{88}$ Muñoz. F. 2012. "Un catálogo de santidad. La segunda parte de la crónica de la provincia franciscana de Burgos" en Atienza, A (Ed), Iglesia Memorable. Crónicas, historias, escritos... a mayor gloria. Siglos XVI-XVIII: 331. Madrid: Sílex.

${ }^{89}$ Valga como ejemplo el abandono del convento de carmelitas de Vitoria, por falta de confesor de la orden, para fundar en Logroño Nta. Sra del Carmen. La historia de esta fundación, que merece ser leída íntegramente, se encuentra recogida en Atienza, A; Catalán, E; Muñoz, F. 2011: $97-107$.

${ }^{90}$ GARAY, Fr. M. 1742: 103-107. Pamplona. Crónica del convento de santa María de Jesús de Navarrete.

${ }^{91}$ Resulta ejemplar la actuación de algunos frailes mercedarios en la villa riojana de Auxejo durante una epidemia de peste. Vega y Toraya, Fr.F. 1723: 677.

92 Un hecho de esta naturaleza se narra en la crónica del monasterio concepcionista de la Madre de Dios de Logroño en el que el cronista se apresura a aclarar que tal comportamiento no se debió a las religiosas de la orden sino a clarisas no reformadas (Hernáez de la Torre, Fr. D., y Saénz de Arquiñigo, Fr. J. 1722: 419). 
No obstante, la mejor y más efectiva muestra de utilidad de la vida conventual, se manifestó a través de sucesos extraordinarios y fantásticos que se interpretaban como signo inequívoco del favor divino. Las crónicas barrocas harán una importante contribución a la eclosión milagrera y a la multiplicación de casos en los que el protagonismo se centraba en lo maravilloso e irreal. ${ }^{93}$ En este sentido, se podría decir que cada orden tenía su especialidad y sus objetos fetiche, que representaban la promesa de redención, siendo elementos propagandísticos de primera magnitud. Los legos que habían adquirido un compromiso público con la orden, se identificaban portando escapularios a los que solían atribuírseles propiedades curativas y un efecto protector ante el mal. ${ }^{94}$ Los fieles se ceñían el cordón franciscano con la esperanza de que el propio san Francisco les sacase del Purgatorio, tal y como prometía la tradición; por analogía, comenzó a usarse como talismán contra el fuego. ${ }^{95}$ Por otra parte, los franciscanos consiguieron, a comienzos del siglo XVI, una bula de León X por la que se otorgaba la reducción efectiva de días de estancia en el Purgatorio a quienes se enterrasen con el hábito de la orden. ${ }^{96}$ No cabe duda de que la transmisión oral y escrita de estos prodigios, envueltos en unos halos misteriosos e imbuidos de propiedades sobrenaturales, incrementó su demanda y, por tanto, la rivalidad entre las órdenes por hacerse acreedoras del más milagroso. Sin duda, los franciscanos se llevaron la palma puesto que la indulgencia concedida a las mortajas junto con las propiedades milagrosas de su cordón, representaban una garantía bastante sólida de lograr una muerte digna y la rápida expiación de los pecados. ${ }^{97}$ Las demás órdenes tuvieron que recurrir a conversiones, apariciones e intervenciones divinas para acrecentar su fama y con ello la cuantía de las limosnas.

En cuestión de milagros, se podría decir que existía un cierto sesgo de género: los conventos masculinos producían más hechos extraordinarios que los femeninos. En las crónicas de los primeros se narran curaciones, salvamentos milagrosos, arrepentimiento de suicidas, extinción de incendios o conversiones de moros; ${ }^{98}$ en cambio, en los segundos no sucede nada extraordinario, salvo alguna aparición que dejaba tras de sí aroma de santidad. ${ }^{99}$ Normalmente, los conventos

${ }^{93}$ Atienza, A; Catalán, E; Muñoz, F. 2011: 46.

94 En la crónica del convento de Trinitarios de Logroño se relata la zozobra de una enferma ante la pérdida de su escapulario y el descenso milagroso de éste desde el cielo, atravesando techos y paredes; en la misma crónica se nos relata un exorcismo y el poder del escapulario frente al demonio. (Ibídem: 90-91).

${ }^{95}$ En las crónicas riojanas aparece en la de los conventos de Calahorra o Alfaro. Además se le atribuían propiedades milagrosas como el suceso de Cornago, donde un hombre intentó ahorcarse con el cordón y no lo consiguió pues el árbol, al que estaba atado, se dobló como si fuese de papel. (Ibídem: 111-112; 134-135 y 184.

96 Martín García, A. 2005. "Religiosidad y actitudes ante la muerte en la montaña noroccidental leonesa: el Concejo de Lanciana en el siglo XVIII" Estudios Humanísticos. Historia, $\mathrm{n}^{\circ}$ 4: $162-163$

${ }^{97}$ La crónica del convento franciscano de Cornago se extiende en explicar los beneficios que los vecinos reciben del convento y como éstos responden con apoyo económico. Hernáez de la Torre, Fr. D., y Saénz de Arquiñigo, Fr. J. 1722:349

98 En la construcción del convento de Nalda, el cantero fue sepultado por un desprendimiento y salió totalmente ileso por intervención de san Antonio o el salvamento de una niña de las profundidades de una sima. Atienza, A; Catalán, E; Muñoz, F. 2011: 162-163, 170, 184185 y $189-192$.

99 “...entró visiblemente nuestra Santa Madre en su celda, y sentándose en la cama, la començó a consolar y con palabras amorosas...Duró la visita hasta que llamaron a Oración y 
femeninos eran descritos como jardines donde florecían la virtud, la humildad, la obediencia o el desprendimiento de las vanidades del mundo. ${ }^{100}$ En estos textos se muestra un tipo de mujer entregada a la oración, volcada en la asistencia a los actos de comunidad y en la observancia rigurosa del "retiro de los seculares". ${ }^{101}$ Este modelo contrasta con el que ofrece Teresa de Jesús en el Libro de las Fundaciones: mujeres valientes y decididas que supieron sortear las dificultades, legales y económicas, para llevar a cabo una empresa de la envergadura de la fundación y expansión del Carmelo descalzo. ${ }^{102}$ La iglesia barroca se esforzó en mostrar mujeres indefensas, necesitadas de tutela y custodia para reforzar el orden social en su triple faceta, la jerárquica, la religiosa y la de género. ${ }^{103}$

A pesar del estrecho margen de maniobra del que disponían las monjas, los conventos femeninos constituyeron un espacio de libertad y de realización personal, difíciles de alcanzar en otros ámbitos. Para unas, la toma de hábito fue la única salida a matrimonios no deseados e incluso forzados en el inicio de la pubertad; ${ }^{104}$ para otras, la toma de hábito constituía una vía de realización personal y la única manera de ostentar ciertas cuotas de poder. Las hijas de la nobleza, que normalmente ocupaban cargos de responsabilidad en los conventos, formaban parte de las relaciones clientelares de sus familias. Por ello los claustros se convirtieron en espacios donde dar y recibir favores y prebendas, con la misma agilidad y eficacia que en la corte, puesto que formaban parte de la misma estructura social. La contrapartida solía ser económica, en forma de limosnas, donaciones o patrocinio permanente, lo que les permitía subsistir con relativa comodidad.

\section{El estímulo del patrocinio privado o la búsqueda de estabilidad económica}

La cuestión económica estuvo muy presente en las crónicas conventuales puesto que los mendicantes, salvo excepciones, no percibían ninguna porción de la masa decimal ni podían poseer propiedades inmuebles. Por ello, la captación de limosnas, donaciones o personas que quisiesen asumir el mantenimiento

desapareciendo la Santa, dexó tal fragancia en el Convento, que despertando las Monjas, y estrañando la novedad acudieron a la celda de la enferma, de donde averiguaron que se originaba el buen olor, y en su rostro y mejoría y después por su confessión supieron la visita, y las palabras que la Santa le dixo de lo mucho que cuidava aquel Convento y el aliviar a sus hijas". Santa María, Fr.F., 1655: 172.

${ }^{100}$ Hernáez de la Torre, Fr. D., y Saénz de Arquiñigo, Fr. J. 1722: 420.

101 Atienza, A; Catalán, E; Muñoz, F. 2011. 2011:51.

102 Sobre este tema véase Catalán Martínez E. 2012a. "La aventura de fundar. La versión heroica de las crónicas religiosas" en Atienza, A. (ed), Iglesia Memorable. Crónicas, historias, escritos.... mayor gloria. Siglos XVI-XVIII: 231-250. Madrid: Sílex.

103 Atienza, A. 2012. "Ceremonia y espectáculo en la fundación de conventos femeninos en la Edad Moderna: la llegada y recepción de las monjas fundadoras” Ma J. Pérez y A. Martín (eds.); F. Fernández Izquierdo (col.) Campo y campesinos en la España Moderna. Culturas políticas en el mundo hispano: 1998. León: Fundación Española de Historia Moderna.

104 En la fundación del convento de carmelitas descalzas de Salamanca se narra la desesperación de la hija menor del Adelantado de Castilla, desposada con tan solo doce años, que se escapa una y otra vez de su casa para ingresar en el convento. (Teresa de Jesús. 1610. Libro de las Fundaciones, Libros 10, 8-16 y 11. Biblioteca Católica Digital). La iglesia intentó atajar la entrada de niñas en los conventos, prohibiendo la entrada en el noviciado antes de los dieciséis años (C.T. Decreto sobre los religiosos y las mojas. Cánones XV y XVII) 
permanente de una de las casas, fueron de vital importancia para la supervivencia de la orden ${ }^{105}$.

La viabilidad de cualquier fundación estuvo ligada a la correcta ubicación del convento y a la prosperidad de la ciudad que lo acogía. Las laudatios fueron una constante en la elaboración de su memoria histórica, puesto que el establecimiento de un convento ennoblecía y sacralizaba el espacio urbano. ${ }^{106}$ Las más antiguas ponían de manifiesto su vinculación con la monarquía, su papel durante la Reconquista, el valor estratégico del enclave o la valentía de sus habitantes; mientras que, las de los nuevos conventos reformados, hacían hincapié en la belleza de sus jardines, la salubridad del clima, lo piadoso de sus gentes o la nobleza y alta cuna de la familia poseedora del solar, si se instalan en tierras de señorío. ${ }^{107}$

La intervención directa del santo fundador sacralizaba el convento y la ciudad que lo acogía, garantizando la veneración de los fieles y por lo tanto las limosnas. Los primeros conventos franciscanos del reino de Castilla se atribuyen a la iniciativa del propio Francisco de Asís, en peregrinaje a Santiago de Compostela. Cierta o no la presencia del santo en el camino, ${ }^{108}$ su mención está cargada de una profunda simbología espiritual y política. En el siglo XII, los reinos cristianos fomentaron la peregrinación a Santiago, patrón de la caballería castellana e incluso del reino, como una forma de consolidarse territorialmente mediante la fundación de sedes episcopales, villas de relevancia estratégica o comercial. Los franciscanos al buscar el protectorado del santo se estaban comprometiendo con los reyes cristianos, en la tarea de reforzar su dominio frente al poder señorial y los monasterios. Por otra parte, el constituía el marco perfecto para iniciarse en el ejercicio de la caridad cristiana a través de la oración, el sacrificio, la humildad y la atención de pobres y enfermos. ${ }^{109}$ La nobleza y la burguesía local, e incluso la monarquía, favorecieron la expansión de la orden a través del sistema de patronazgo que permitía garantizar la financiación sin acumular bienes inmuebles. 110 El linaje del patrocinador se ensalzaba con virtudes de heroísmo, lealtad y

${ }^{105}$ El tema del patrocinio de conventos por las élites tanto locales como nacionales es ampliamente tratado por Atienza, A. 2008. Tiempos de conventos. Una historia social de las fundaciones en la España moderna. Madrid: Marcial Pons Historia

${ }^{106}$ Atienza, A; Catalán, E; Muñoz, F. 2011:40.

107 Las laudatios de las villas de Alfaro, Logroño o Nalda muestran tintes de poemas épicos con descripciones heróicas (Hernáez de la Torre y Saénz de Arquíñigo. 1722: 357,397 y 418), aunque en versiones posteriores se centran más en su valor estratégico (Garay, Fr. M. 1742: 19)

108 En el imaginario franciscano, el fundador recibió la orden de erigir nuevos conventos a los pies del sepulcro del apóstol, lo que se apresuró a realizar en el camino de vuelta a Italia. No existe acuerdo entre los historiadores de la orden sobre la veracidad de esta información, aunque los testimonios escritos de este viaje se remontan hasta el siglo XIV. (Alonso del Val, J.Ma OFM. 1996. "Los primeros conventos franciscanos en la provincia seráfica de Burgos", en De la Iglesia Duarte, García Turza, García de Cortázar, J.A. (coords.), VI Semana de Estudios Medievales : Nájera, 31 de julio al 4 de agosto de 1995: 272-276. Nájera: Instituto de Estudios Riojanos y Ormaechevarría, I. Fr. 1962. "San Francisco de Asís en la Rioja”. Berceo LXV: 402

109 El peregrinaje como símbolo del viaje interior se encuentra en el estoicismo romano, en varios pasajes bíblicos, en la patrística cristiana y es ensalzado durante el Medievo como un proceso de purificación y una existencia cotidiana presidida por las obras pías. Beceiro, I. 2007. "De las peregrinaciones al viaje interior. Las transformaciones en la religiosidad nobiliar castellana" Cahiers de linguistique hispanique médiévale, 30: 120-125

${ }^{110}$ La abundancia de Iglesias de patronato en cantábrico oriental y Navarra, propició que se siguiera el mismo esquema a la hora de financiar económicamente la erección de un convento: el patrón proporcionaba los medios materiales de presente y futuro a cambio de asiento y 
servicio a la corona, lo que servía de pretexto para glorificarla. ${ }^{111}$ La connivencia con la clase dirigente, la institucionalización de las fundaciones y los privilegios que recibieron de los reyes, ${ }^{112}$ propiciaron un alejamiento de los principios evangélicos y una severa relajación de costumbres que no se mencionan en las crónicas, aunque fueran la causa de la reforma descalza. A partir del proceso de renovación de la vida conventual, iniciado por el cardenal Cisneros, se pondrán de manifiesto las virtudes de la vida ascética para alcanzar la santidad, integrando la figura del patrón en ese contexto.

La memoria histórica del Carmelo descalzo omite cualquier referencia anterior a Teresa de Jesús, aunque redescubre elementos medievales adaptándolos a la mentalidad barroca. Por ejemplo, los viajes fundacionales, presentes en todas las crónicas carmelitanas, retoman la tradición del peregrinaje como vía de purificación; o el empeño de Teresa de Jesús en conservar su independencia económica, impulsando las fundaciones de pobreza reivindican el ideario de vida ascética de los primeros mendicantes.

A partir de la década de 1580, se generalizó en todas las órdenes el patrocinio de la nobleza puesto que las autoridades eclesiásticas y civiles lo exigían como requisito indispensable para otorgar las licencias oportunas. ${ }^{113}$ Para las monjas no existía otra opción de supervivencia, especialmente desde que Trento las obligara a vivir en clausura ${ }^{114}$ reduciendo sus posibilidades de autosuficiencia económica a la mínima expresión e incluso condenándolas a la desaparición. ${ }^{115} \mathrm{La}$ mayoría de las órdenes aceptaron las pretensiones de aquellos candidatos que se comprometieran a correr con los gastos de la casa, reconociéndoles, a cambio, derechos de enterramiento y asiento preferente, símbolos inequívocos de posesión de un patronato. A partir del siglo XVII esta práctica se hizo habitual, aunque circunscrita a una determinada capilla en el interior de la iglesia conventual ${ }^{116}$, lo que permitió la diversificación de los benefactores y la generalización de un privilegio compartido.

A pesar de que, en principio, los patrones cubrían las necesidades básicas de los conventos, éstos no estuvieron exentos de problemas económicos. Con cierta frecuencia, los compromisos adquiridos en la fundación se rompieron por diversas causas, dejando al convento desvalido y sin medios ni recursos legales

enterramiento preferente, y oraciones por la salvación de su alma y la de sus familiares. Este tipo de acuerdos contrastaba con las abundantes donaciones de tierras y bienes que habían recibido los grandes centros monásticos del Medievo.

111 Las crónicas de los conventos franciscanos de Logroño y Alfaro dan buena fe de ello. Atienza, A; Catalán, E; Muñoz, F. 2011: 65-68 y 130-131

112 Entre los privilegios que recibieron franciscanos y clarisas estaban el derecho de predicar, tener campanas, poseer cementerio propio, no pagar el diezmo por sus propiedades y acudir a las procesiones con su cruz en alto. (Rucquoi, A. 1996: 70).

${ }^{113}$ Catalán, E. 2012: 234-237; 245-246

114 C.T. Sesión XXV. Decretos de Reforma, canon V.

115 "Llego este monasterio (Alfaro) a tan lastimoso estado de la mayor pobreza que, no arbitrando modo para remedio de tanta necesidad, estuvo a punto de derruirse y distribuir sus religiosas a diversos conventos de la Provincia (...) sentía el Pueblo su aflicción, y remediaban las los vecinos con lo que podían, sirviéndoles de desconsuelo no poderlas dar competentes rentas para su perpetua manutención" Hernáez de la Torre y Saénz de Arquiñigo.1722: 426.

116 "Dize que por los años de mil quinientos ochenta y dos, se dio a los señores Don Álvaro de Luna y a la Señora Doña María Curiel, su esposa, y no fue así, porque sólo se dio el Patronato de la Capilla Mayor..." Fr. Manuel de Garay, 1742:141-142) 
para conseguir otras fuentes de financiación. En las crónicas, las desavenencias entre patrocinador y patrocinado aparecen veladas, o sutilmente insinuadas, puesto que el honor de las familias implicadas no debe verse amenazado. Al contrario, el panegírico que se hace de sus virtudes constituye un elemento clave de su preeminencia social; del mismo modo que lo son el título, el blasón, o el derecho de ocupar un lugar preferente en las manifestaciones públicas. En la sociedad barroca, el patronazgo representaba un preciado capital social que permitía mostrar públicamente el compromiso de la familia y del linaje con la fe católica, reforzando el orden jerárquico establecido.

\section{CONCLUSIONES}

A partir de Trento se inició un camino hacia la iglesia universal en la que los vínculos de vasallaje fueron perdiendo todo su significado para dar paso al sentimiento de parroquialidad como principal manifestación de pertenencia a una comunidad. La profesionalización del clero fue un elemento decisivo para consolidar unas relaciones sociales dominadas por la verticalidad y la preeminencia social. La nueva identidad sacerdotal, basada en su sometimiento a la autoridad episcopal, en la diferenciación inequívoca con los regulares y en la manifestación pública de un comportamiento ejemplar, no se generalizó en las diócesis del arco cantábrico hasta mediados del siglo XVIII. Fue entonces, cuando la política de disgregación del patrimonio eclesiástico de la nobleza consiguió debilitar el poder de los patronos frente al obispo y se reforzó la capacidad económica de los curatos gracias a la percepción íntegra de los frutos de los nuevos quebrantes.

En cambio, la popularización de la teoría del Purgatorio, el fomento de la vocación mariana, el culto a los santos o el patrocinio conventual penetraron rápida y profundamente en la sociedad medieval, transformándola. El patrocinio de un convento, entroncaba muy bien con la tradición medieval de la iglesia propia situando a la familia fundadora en un plano moral superior. A diferencia de las capellanías, que velaban por la salvación privada de la familia instituyente, la financiación de un convento permitía contribuir a la formación de nuevos santos, con el consiguiente incremento del capital social de los benefactores. La eclosión milagrera produjo un inmediato efecto propagandístico que produjo un auténtico boom fundacional y un incesante flujo de mandas testamentarias, legados píos y limosnas, aun en época de grave crisis económica.

\section{BIBLIOGRAFÍA}

Alonso del Val, J.M ${ }^{a}$ OFM. 1996. "Los primeros conventos franciscanos en la provincia seráfica de Burgos" en De la Iglesia Duarte, García Turza y García de Cortázar, (coord.), VI Semana de Estudios Medievales. Nájera, 31 de julio al 4 de agosto de 1995: 271-282. Nájera: Instituto de Estudios Riojanos.

Arranz Guzmán, A. 2008. "Celibato eclesiástico, barraganas y contestación social en la Castilla bajomedieval". Espacio, Tiempo y Forma, Serie III, Historia Medieval, 21: 13-39

Atienza, A. 2012. "Ceremonia y espectáculo en la fundación de conventos femeninos en la Edad Moderna: la llegada y recepción de las monjas fundadoras" Comunicación presentada a la XII reunión científica de la 
Fundación española de Historia Moderna. León 20-22 de Junio de 2012 (inédita)

Atienza, A; Catalán, E; Muñoz, F. 2011. Conventos de la Rioja. Su historia en las crónicas religiosas de época barroca. Logroño: Instituto de Estudios Riojanos.

Beceiro, I. 2007. "De las peregrinaciones al viaje interior. Las transformaciones en la religiosidad nobiliar castellana" Cahiers de linguistique hispanique médiévale, 30: 109-125.

Barrio Gozalo, M. 2010. El clero en la España Moderna. Córdoba: Caja Sur y CSIC.

Caffiero, M. 1994. "Tra modelli di disciplinamento e autonomia soggettiva", en Barone, G; Caffiero, M y Scorza, F (ed.) Modelli di santità e modelli di comportamento: 265-279. Torino: Rosenberg\&Sellier

Candau Chacón, M $^{a}$.L, 1993. Los delitos y las penas en el mundo eclesiástico sevillano del XVIII. Sevilla: Diputación provincial.

Catalán Martínez, E. 2000. El precio del purgatorio. Los ingresos del clero vasco en la Edad Moderna. Bilbao: Servicio Editorial de la Universidad del País Vasco.

Catalán Martínez, E. 2004. "El derecho de patronato y el régimen beneficial de la iglesia española en la Edad Moderna", Hispania Sacra, Vol. LVI, 113: 135-168.

Catalán Martínez, E. 2010. "La participación del bajo clero en el excedente agrario vasco y riojano (1545-1775). Investigaciones de Historia económica, 18: 3566.

Catalán Martínez, E. 2012a. "La aventura de fundar. La versión heroica de las crónicas religiosas" en Atienza López, A (Ed), Iglesia Memorable. Crónicas, historias, escritos... a mayor gloria. Siglos XVI-XVIII, Madrid: Silex (en prensa).

Catalán, E. 2012b. "La parroquia, ese oscuro objeto de deseo: patronato, poder y conflicto en el País Vasco (s. XIII-XVII)" Comunicación presentada a la XII reunión científica de la Fundación española de Historia Moderna. León 20-22 de junio de 2012 (inédita)

Constituciones Sinodales, 1554. Constituciones synodales del Obispado de Calahorra y la Calzada, hechas y ordenadas por los prelados, agora nuevamente compilados y añadidos por el Illustre y Reverendisimo señor Don Ion Bernal de Luco, obispo del dicho obispado y del Consejo de su Magestad, con acuerdo del Synodo que por su mandado se celebró en la ciudad de Logroño, anno de 1553. Logroño.

De Cisneros, C.; Larhacha, E; Lorente, A.; Martínez, A. (compiladores).1986. Fuentes jurídicas medievales del Señorío de Vizcaya. San Sebastián: Eusko-lkaskuntza.

Egido, T. 2000. "Hagiografía y estereotipos de santidad contrarreformista" Cuadernos de Historia Moderna, 25, monográfico: 61-85.

Fernández Conde, F.J. 2000. La religiosidad medieval en España: Plena Edad Media (ss. XVI-XII) Oviedo: Universidad de Oviedo

Fernández Terricabras, I. 2000. Felipe Il y el clero secular. La aplicación del concilio de Trento. Madrid: Sociedad Estatal para la conmemoración de los centenarios de Felipe II y Carlos V.

Fernández Terricabras, I. 2002. "Universidad y episcopado en el siglo XVI. Las universidades donde estudiaron los obispos de las coronas de Castilla y de Aragón (1556-1598) Revista de Historia Moderna. Anales de la Universidad de Alicante, 20: 5-44. 
Fonseca, J. 1996. El clero en Cantabria en la edad moderna: un estudio sobre la implantación de la contrarreforma en el norte de España. Santander: Servicio de publicaciones de la Universidad de Cantabria.

Garay, Fr. M. 1742. Compendio chronológico con nuevas adiciones a la Primera parte de la Crónica de la Santa Provincia de Burgos, Pamplona.

Hernández, J.L. y Sánchez, L. 2010. "Hacia la racionalización de la formación sacerdotal: orígenes, tentativas y el Concilio de Trento (1545-1563)". Educa B. Revista de la escuela de educación, 2: 73-114.

Hernáez de la Torre, Fr. D., y Saénz de Arquiñigo, Fr. J. 1722. Primera Parte de la Chronica de la Provincia de Burgos de la Regular Observancia de Nuestro Padre San Francisco, Madrid.

Iglesias Ortega, A. 2011. "La perpetuación de la sangre: la descendencia ilegítima del alto clero compostelano en el siglo XVI" Manuscrits 29: 137-155.

Irigoyen, A. 2008. "Los tratados de perfección sacerdotal y la construcción de la identidad social del clero en la España del siglo XVII" Hispania, 230: 707-734.

Irigoyen, A. 2010, "La difícil aplicación de Trento. Las faltas de los capitulares en Murcia (1592-1622)" Hispania sacra, 125: 157-179.

Jedin, U. 1963. " L'importanza del decreto Tridentino sui seminarinella vita della Chiesa". Seminarium 2: 397-398.

Lepe, Pedro. 1690. Carta general que ... Pedro de Lepe, Obispo de Calahorra y la Calzada ... escriue a todo su obispado en razón del silencio, veneración y modestia con que se debe assistir en la iglesias y lugares públicos de oración, y de la enmienda y total extirpación de los muchos abusos que en contrario se experimentan. Logroño.

Mañaricúa, A. 1975. "Problemas religiosos en la Vizcaya de los siglos XIV y XV; régimen monasterial, jurisdicción episcopal y decadencia religiosa" en $L a$ sociedad vasca rural y urbana en el marco de la crisis de los siglos XIV y XV: 256. Bilbao: Diputación Foral de Vizcaya.

Martín García, A. 2005. "Religiosidad y actitudes ante la muerte en la montaña noroccidental leonesa: el Concejo de Lanciana en el siglo XVIII" Estudios Humanisticos. Historia, 4: 149-175.

Muñoz. F. 2012. "Un catálogo de santidad. La segunda parte de la crónica de la provincia franciscana de Burgos" en Atienza López, A (Ed.), Iglesia Memorable. Crónicas, historias, escritos... a mayor gloria. Siglos XVI-XVIII, Madrid: Silex (en prensa).

Muro Abad, J.R. 1993."La castidad del clero bajomedieval en la diócesis de Calahorra”, Historia. Instituciones. Documentos, 20: 262-282.

Muro Abad, J.R 1994." El clero diocesano vasco en los siglos XV y XVI: una imagen "en E. García Fernández (Dir.), Religiosidad y sociedad en el País vasco (s. XIV-XVI): 53-82. Bilbao: Servicio editorial de la Universidad del País Vasco.

Navarro, A.M. 2010. "Los santos y el imaginario urbano en los discursos historiográficos: Andalucía siglos XIII-XVII". Hispania Sacra 126: 457-489.

Ormaechevarría, Fr.I. 1962. "San Francisco de Asís en la Rioja" Berceo, LXV, Logroño: 399-407.

Pérez-Embid, J. 2002. Hagiología y sociedad en la España medieval. Castilla y León (siglos XI-XIII). Huelva: Publicaciones de la Universidad de Huelva.

Puigvert, J, 2001. Església, territorio i sociabilitat (s. XVII-XIX). Vic: Eumo editorial.

Rucquoi, A. 1996. "Los franciscanos en el Reino de Castilla" " en De la Iglesia Duarte, García Turza, García de Cortázar (coords), VI Semana de Estudios 
Medievales: Nájera, 31 de julio al 4 de agosto de 1995: 65-86. Nájera: Instituto de Estudios Riojanos.

Sacrosanto, Ecuménico y General Concilio de Trento. 1563. Biblioteca Electrónica Cristiana (B.E.C.) [http://multimedios.org/docs/d000436/] <consultado en Marzo 2012>.

Sáenz Ripa, E. 1990. Los obispos de Calahorra en la Edad Media (siglos VIII-XV). Logroño: Instituto de Estudios Riojanos.

Sala Balust, L. y Martín Hernández, F. 1966. La formación sacerdotal en la Iglesia. Barcelona: Juan Flors editor.

Sánchez Herrero, J. 2008. "Amantes, barraganas, compañeras, concubinas clericales". Clio\& Crimen. 5: 106-137.

Santa María, Fr. F. 1655. Reforma de los Descalzos de Nuestra Señora del Carmen de la primitiva observancia hecha por Santa Teresa de Jesús en la antiquíssima Religión fundada por el gran profeta Elías. Tomo Segundo: 504515. Madrid.

Sangalli, M. 2007. "La formación del clero católico en la Edad Moderna. De Roma, a Italia, a Europa". Manuscrits 25: 101-128.

Soto Rábanos, J.M. 2006. "Visión y tratamiento del pecado en los manuales de confesión de la Baja Edad Media Hispana". Hispania Sacra, 118: 411-447.

Teresa de Jesús. 1610. Libro de las Fundaciones, Biblioteca Católica digital, [http://www.mercaba.org/FICHAS/Santos/TdeJesus/fundaciones 00.htm] $<$ consultado en febrero 2011>

Vega y Toraya, Fr. F. de la. 1723. Chronica de la Provincia de Castilla y León, y Navarra del orden de la Santíssima Trinidad, Redempción de Cautivos. Segunda parte: 675-681. Madrid.

Wright, A.D. 1991. Catholicism and Spanish Society under the reign of Philip II and Philip III. Lewiston-Queenston-Lampeter: The Edwin Mellen Press. 